\title{
Controlling Water Hyacinth, Eichhorni acrassipes (Mart.) Solms Using Some Selected Eco-Friendly Chemicals
}

\author{
Aklilu Agidie $^{1 *}$, Samuel Sahle ${ }^{2}$, Adugnaw Admas ${ }^{3}$ and Mehari Alebachew ${ }^{3}$ \\ ${ }^{1}$ Bahir Dar Environment and Forest Research Center, Bahir Dar, Ethiopia \\ ${ }^{2}$ Department of Biology, University of Gondar, Gondar, Ethiopia \\ ${ }^{3}$ Ethiopian Environment and Forest Research Institute, Addis Ababa, Ethiopia
}

\begin{abstract}
Water hyacinth is one of the world's worst invasive weed. The weed has invaded Lake Tana. This study has been carried out with the aim of investigating the effect of some selected chemicals to control water hyacinth at shade level. The experimental design used was a Complete Randomized Design (CRD) with three replications. The plants were submerged thoroughly with different concentrations per treatment. The data was collected at a scale of $0 \%$ to $100 \%$ inhibition. Five eco-friendly chemical compounds, namely: Sodium chloride $(\mathrm{NaCl})$, Potassium chloride $(\mathrm{KCl})$, Glyphosate $\left(\mathrm{C}_{3} \mathrm{H}_{8} \mathrm{NO}_{5} \mathrm{P}\right)$ and acetic acid $99 \%\left(\mathrm{CH}_{3} \mathrm{COOH}\right)$ with three concentrations $(15 \%, 20 \%$ and $25 \%)$ were applied on foliar application under shade. Acetic acid and Glyphosate chemicals performed well in the controlling water hyacinth. The result indicated that, the efficacy increased as the concentration increased from $15 \%$ to $25 \%$. Acetic acid showed significant variation compared to control, $\mathrm{NaCl}$, and $\mathrm{KCl}$ at $(\mathrm{p}<0.01)$ and able to shrink and kill the water hyacinth tissue within a few days as compared to other treatments. $20 \%$ and $25 \%$ Glyphosate application rate also shrunk the leaves of water hyacinth gradually and the result was not statistically significantly different from the acetic acid treatment. Hence, Acetic acid $99 \%$ can be used as an option to control this weed.
\end{abstract}

Keywords: Water hyacinth; Aquatic weed; Eco-friendly; Environment; Herbicide; Invasive weed

\section{Introduction}

The presence of water hyacinth in Lake Tana has been recognized in 2011 [1-7]. Water hyacinth was observed in the Lake Tana basin around river mouths where the nutrient condition was relatively good, and the water quality condition has started to deteriorate. in Gondar Zuria and Dembia districts. The weed is very notorious and can cover the whole lake in a few years' time if immediate control strategies are not in place. It can destroy the fishery industry; create obstacles to navigation, clog canals of hydroelectric power plants and which creates serious environmental imbalance [8-10]. Starting from the last five years, especially after 2014, fishing in the study area becomes tiring due to the expansion of this invasive weed. Water hyacinth entangles the fishing nets and boats' propeller, making it difficult to fish and resulting in reduced fish catches. Hence, a reduced fish catch would have an adverse effect on the quality of life of the communities around the lake and consequently affect sustainable development in the region. Despite the fact that several efforts have been made by different parties, water hyacinth in Lake Tana continues to expand itself year after year. Therefore, its expansion is not easy to manage and complete eradication is unimaginable. Therefore, if the expansion of water hyacinth continues in this trend, it can negatively affect the livelihood of fishers in both directions by increasing costs of fishing and reducing the amount of fish caught [11-16]. The use of chemicals for aquatic vegetation control is one issue commonly surrounded with fear and uncertainty by general public, environmental groups, and politicians [2]. Moreover, scientists and environmentalist argue that chemical control of aquatic plants treats the symptom rather than the source of the problem [17-21]. Controlling water hyacinth plant is difficult due to its biomass and the leaf turnover rate is high with about $60 \%$ to $70 \%$ of leaves being replaced each month. The common controlling options, mechanical and manual removals, are almost the only ways approved to control the water hyacinth in different countries. But they are largely unsuccessful. Tremendous effort has been put into the control of the water hyacinth, with varying degrees of success [16-19]. Invasive species are widely accepted as one of the leading causes of biodiversity loss and can have significant effects on resource availability and can suppress the relative abundance of native species $[6,15]$. In Ethiopia, close to 35 invasive alien plant species are posing negative impacts on native biodiversity, agricultural lands, rangelands, national parks, waterways, lakes, rivers, power dams, roadsides, urban green spaces with great economy and social consequence [22]. Chemical control of aquatic weeds has become of increased due to great awareness of the need for weed control. In addition, the value placed on irrigation as well as fishing and amenity requirement plus increased cost of labor has created substantial interest in weed control by chemicals. Diquats, Paraquat, are extremely soluble in water and acts as contact weed killer [11]. Therefore, this study was initiated with aim of investigating the role of selected eco-friendly chemicals for controlling water hyacinth at shade level.

\section{Materials and Methods}

The experiment was conducted at the geographical location of $11^{\circ} 36^{\prime} 00^{\prime \prime} \mathrm{N}$ and $037^{\circ} 25^{\prime} 22.9^{\prime \prime} \mathrm{E}$ and its elevation is 1829 meter above sea level in Bahir Dar Environment and Forest Research Center campus under shade. The experimental design used was a Complete Randomized Design (CRD) with three replications. Chemicals such as acetic acid $99 \%, \mathrm{NaCl}, \mathrm{KCl}$, and Glyphosate with three concentrations $(15 \%, 20 \%$ and $25 \%)$ to see effect of chemicals with different level and water as a control treatment. Single plants were placed separately into plastic pots $(26 \mathrm{~cm}$ height $\times 27 \mathrm{~cm}$ diameter, each containing 10 liters

*Corresponding author: Aklilu Agidie, Bahir Dar Environment and Forest Research Center P.O. Box 2128 Bahir Dar, Ethiopia, Tel: 251947050640; E-mail: aklsm@yahoo.com

Received May 27, 2017; Accepted January 12, 2018; Published January 15, 2018

Citation: Agidie A, Sahle S, Admas A, Alebachew M (2018) Controlling Water Hyacinth, Eichhorni acrassipes (Mart.) Solms Using Some Selected Eco-Friendly Chemicals. J Aquac Res Development 9: 521. doi: 10.4172/2155-9546.1000521

Copyright: @ 2018 Agidie A, et al. This is an open-access article distributed under the terms of the Creative Commons Attribution License, which permits unrestricted use, distribution, and reproduction in any medium, provided the original author and source are credited. 
Citation: Agidie A, Sahle S, Admas A, Alebachew M (2018) Controlling Water Hyacinth, Eichhorni acrassipes (Mart.) Solms Using Some Selected Eco-Friendly Chemicals. J Aquac Res Development 9: 521. doi: 10.4172/2155-9546.1000521

Page 2 of 3

of water. The plants were immersed thoroughly with $200 \mathrm{ml}$ of the different concentrations per treatment. Based on Tarek (2015) the data was collected at a scale of $0 \%$ to $100 \%$ inhibition $(0$ means no reaction, recorded percentage shows the killing capacity of the chemical and 100 means total inhibition of the weed tissue by the chemical) within 10 days. Fresh weight was recorded before spray and at the end of ten days.

\section{Data Analysis}

The collected data was analyzed using Microsoft EXCEL and R software program and the group mean were computed using ANOVA.

\section{Results and Discussion}

Acetic acid showed statistically highly significant $(\mathrm{p}<0.01)$ in addition to shrinking and killing water hyacinth tissue in comparison with other treatments. The effectiveness of chemicals increased as their concentration was increased from $15 \%$ to $25 \%$. The highest concentration (25\%) was most effective compared with the low (15\%) and medium (20\%) concentrations. Acetic acid controlled the growth of water hyacinth by $100 \%$. Glyphosate worked well at the medium and high concentrations, but it took more than five days to kill tissues of water hyacinth. Acetic acid changed the leaves of the weed to dark green and then brown color. Sodium chloride and Potassium chloride only damaged the leaf tip edge (Figure 1). Acetic acid affected the stem, the stolen and leaf part of the water hyacinth sufficiently within short time as compared to others (Figure 1). Visual follow-up that was made several hours after treatment showed rapid phytotoxic to water hyacinth plant. The leaves color changed and the plant biomass shrunk (Table 1). This experimental study was held under shade. Some research
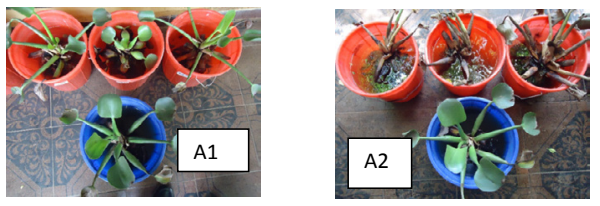

(A1 and A2): Effect of acetic acid.
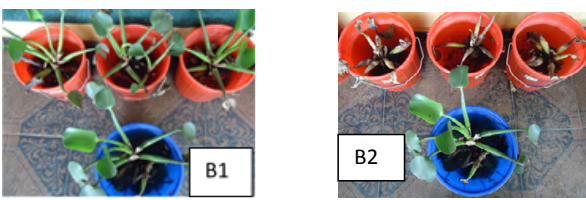

(B1 and B2): Glyphosate.
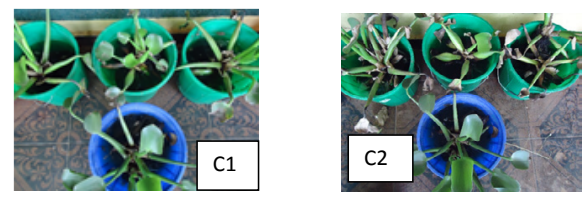

(C1 and C2): Sodium chloride.
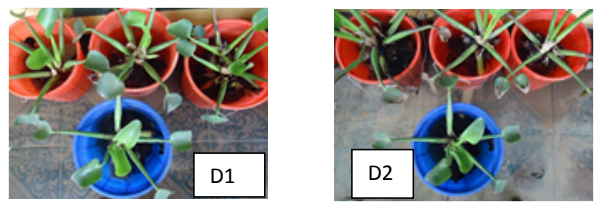

(D1 and D2): Potassium chloride.

Figure 1: Before and after spray respectively within ten days. (1 means, before spray and 2 means, after 10 days).

\begin{tabular}{|c|c|c|c|c|c|}
\hline \multirow{2}{*}{$\begin{array}{c}\text { Treatment } \\
\text { type }\end{array}$} & \multirow{2}{*}{ Concentration } & \multicolumn{3}{|c|}{ Inhibition (\%) } & \multirow{2}{*}{ Treatment Mean } \\
\hline & & Rep.1 & Rep.2 & Rep.3 & \\
\hline \multirow{4}{*}{$\mathrm{NaCl}$} & $15 \%$ & 50 & 50 & 60 & 53.33 \\
\hline & $20 \%$ & 70 & 60 & 60 & 63.33 \\
\hline & $25 \%$ & 60 & 50 & 70 & 60.00 \\
\hline & Control & 0 & 0 & 0 & 0.00 \\
\hline \multirow{4}{*}{$\mathrm{KCl}$} & $15 \%$ & 55 & 60 & 40 & 51.67 \\
\hline & $20 \%$ & 50 & 40 & 50 & 46.67 \\
\hline & $25 \%$ & 50 & 50 & 65 & 55.00 \\
\hline & Control & 0 & 0 & 0 & 0.00 \\
\hline \multirow{4}{*}{$\begin{array}{c}\text { Acetic Acid } \\
99 \%\end{array}$} & $15 \%$ & 100 & 100 & 100 & 100.00 \\
\hline & $20 \%$ & 100 & 100 & 100 & 100.00 \\
\hline & $25 \%$ & 100 & 100 & 100 & 100.00 \\
\hline & Control & 0 & 0 & 0 & 0.00 \\
\hline \multirow{4}{*}{ Glyphosate } & $15 \%$ & 89 & 89 & 92 & 90.00 \\
\hline & $20 \%$ & 88 & 89 & 90 & 89.00 \\
\hline & $25 \%$ & 87 & 88 & 89 & 88.00 \\
\hline & Control & 0 & 0 & 0 & 0.00 \\
\hline \multicolumn{5}{|c|}{ Grand mean } & 56.90 \\
\hline \multicolumn{5}{|c|}{ CV } & 8.79 \\
\hline \multicolumn{5}{|c|}{ LSD5\% } & 7.92 \\
\hline \multicolumn{5}{|c|}{ LSD1\% } & 10.54 \\
\hline
\end{tabular}

Table 1: Effect of sprayed chemicals on water hyacinth biomass at different concentration.

\begin{tabular}{|c|c|c|}
\hline Treatment type & Treatment Mean & Difference from control \\
\hline $\mathrm{NaCl} 15 \%$ & $53.33^{\mathrm{de}}$ & -35.67 \\
\hline $\mathrm{NaCl} 20 \%$ & $63.33^{c}$ & -25.67 \\
\hline $\mathrm{NaCl} 25 \%$ & $60^{\text {cd }}$ & -29 \\
\hline $\mathrm{KCl} 15 \%$ & $51.67^{\mathrm{e}}$ & -37.33 \\
\hline $\mathrm{KCl} 20 \%$ & $46.67^{f}$ & -42.33 \\
\hline $\mathrm{KCl} 25 \%$ & $55^{\mathrm{d}}$ & -34 \\
\hline Acetic acid $15 \%$ & $100^{\mathrm{a}}$ & $11^{* *}$ \\
\hline Acetic acid $20 \%$ & $100^{\mathrm{a}}$ & $11^{* *}$ \\
\hline Acetic acid $25 \%$ & $100^{\mathrm{a}}$ & $11^{* *}$ \\
\hline Glyphosate $15 \%$ & $90^{\mathrm{ab}}$ & 1 \\
\hline * Glyphosate $20 \%$ & $89^{a b}$ & 0 \\
\hline Glyphosate $25 \%$ & $88^{b}$ & -1 \\
\hline \multicolumn{3}{|c|}{$\begin{array}{l}\text { ** Significant at } 1 \% \text { level, *Significant at } 5 \% \text { level, ns=Not Significant } \\
\star \text { Glyphosate average percentage was compared with other treatments. } \\
\text { Superscript values represent significant difference of treatments. }\end{array}$} \\
\hline
\end{tabular}

Table 2: Significant difference of treatments.

results reported that the exposure to sunlight increases the herbicidal and chemical efficiencies [21]. Additionally, the report revealed that symptoms occurred faster in bright sunlight. The effects appeared within some minutes of application under bright sunlight, while the effects took longer hours in the absence of sunlight. The use of the acetic acids showed good activity in controlling water hyacinth, as compared to glyphosate. Glyphosate (Round up) is the world's most heavily used weed killer [18]. The herbicidal activity was concentration dependent. The chemicals had a burning effect on the plants. The effects appeared clearly within hours of the treatment, which supports the action of the chemicals as contact herbicides. They caused foliage color change followed by death as an eventual result. The result is consistent with those of researchers who suggested that the mechanism of action of such chemicals is similar to that of paraquat and diquat herbicides since the chemicals cause rapid dissolution of cell membrane integrity resulting in desiccation of foliar tissues, and ultimately plant death $[13,14]$ Statistical difference between the treatment means and the control treatment is indicated (Table 2). The examined chemicals, particularly, acetic acid and glyphosate showed better efficacy in suppressing the 


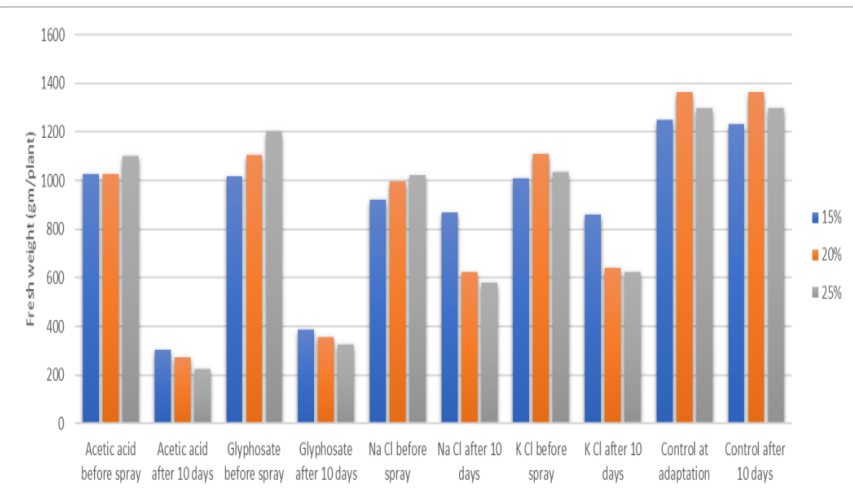

Figure 2: Fresh weight of biomass (gm/plant) before spray and after ten days.

water hyacinth tissue growth when applied at different concentrations. Fresh weight biomass (gm/plant) before spray was recorded around $1000 \mathrm{gm} /$ plant and it shrunk to $200 \mathrm{gm} /$ plant due to the chemicals high dehydration capacity ten days after spray (Figure 2). Acetic acid showed statistically highly significant $(\mathrm{p}<0.01)$ which able to shrink and kill the water hyacinth tissue in comparison with other treatments. $\mathrm{NaCl}$ and $\mathrm{KCl}$ showed poor performance in controlling the weed. Acetic acid able to penetrate the membrane [5]. Once inside the organelle it will continue to break down the important molecules which reduce carbohydrate formation and influences plant growth. Using chemicals to control water hyacinth has its own effect in terms of environment, economic feasibility, water use and acceptance by the beneficiaries. Some researchers had reported that chemical control, through the use of certain herbicides seems to be an economically feasible option in some countries, but not in others with less economic development [17]. In addition, in many countries public opinion is strongly against the use of chemicals in water, which is used for drinking purposes [3]. Acetic acid is effective because it lowers total chlorophyll at all-time preplant applications. Acetic acid concentration significantly affects weed shoots and reduces the growth of plant height, leaf area and stunting the plants [20-22]. Acetic acid, the component of vinegar, have been well documented as safe, effective, and cheap herbicides for controlling terrestrial weeds $[8,12,18]$. However, little is mentioned about their influence as aquatic herbicides [4].

\section{Conclusion and Recommendations}

The examined chemicals, particularly, acetic acid and glyphosate showed better efficacy in suppressing the water hyacinth tissue growth when applied at different concentrations. Fresh weight biomass shrunk due to the chemicals high dehydration capacity ten days after spray. This experiment was found that Acetic acid affected the stem, the stolen and leaf part of the water hyacinth sufficiently within short time as compared to other chemicals. Effectiveness increases as its content and application volume increases. Single chemical was examined for each treatment in this study. But different research observations discussed that using chemicals in mixtures increases potential of herbicidal activity and remained the best in terms of efficiency and speed of activity. In general, Acetic acid chemical can be taken as an option to control the water hyacinth and perceived as environmentally pleasant product and need further investigation.

\section{References}

1. Abouziena HFH, Omar AAM, Sharma SD, Singh M (2009) Efficacy comparison of some new natural-product herbicides for weed control at two growth stages. Weed Technol 23: 431-437.

2. Adekoya BB (2000) Chemical control of water hyacinth (eichhornia crassipes at ere, ogun state, nigeria: Implications for aquatic and terrestial biodiversity conservation. Paper presented at the International Conference on Water Hyacinth, held at New Bussa, Nigeria.

3. Ainsworth R (2004) Safe piped water: Managing microbial water quality in piped distribution systems. IWA Publishing, London, for the World Health Organization, Geneva, Switzerland.

4. Anderson LWJ (2007) Potential for sediment-applied acetic acid for control of invasive Spartina alterniflora. J Aquatic Plant Manag 2: 1.

5. Barchok M (1999) What type of effects could vinegar have on a plant watered with it? MadSci Network.

6. Bhattacharya A, Haldar S, Chatterjee PK (2015) Geographical distribution and physiology of water hyacinth (Eichhornia crassipses) the invasive hydrophyte and a biomass for producing xylitol. Int J Chem Tech Res 7: 1849-1861.

7. Asmare E (2017) Current trend of water hyacinth expansion and its consequence on the fisheries around north eastern part of Lake Tana, Ethiopia. J Biodivers Endanger Species 5: 2

8. Frederickson ME, Greene MJ, Gordon DM (2005) Ecology: Devil's gardens bedevilled by ants. Nature 437: 495-496.

9. Gettys LA, Haller TH, Petty DG (2014) Aquatic plant management: best management practices in support of fish and wildlife habitat and Biology and control of aquatic plants: A best management practices handbook (3rd edn), Aquatic Ecosystem Restoration Foundation, USA.

10. Shimelis G (2017) Problem overview of the lake tana basin. social and ecological system dynamics, aess interdisciplinary Environ Studies Sci Ser.

11. Pizzutti IR, Vela GM, De Kok A, Scholten JM, Dias JV, et al. (2016) Determination of paraquat and diquat: LC-MS method optimization and validation.

12. Ivany JA (2010) Acetic acid for weed control in potato (Solanum tuberosum L.). Canadian J Plant Sci 90: 537-542.

13. Murphy TR (1999) Turfgrass herbicide mode of action and environmental fate. The University of Georgia. Atlanta, Georgia.

14. Owen MDK (2002) Acetic acid (vinegar) for weed control revisited. Integrated Crop Manage:

15. Patel S (2012) Heats management and envisaged utilizations of aquatic weed Eichhornia crassipes: An overview. Rev Environ Sci Biotechnol 11: 249-259.

16. Ray P, Kumar S, Pandey S (2009) Impact evaluation of neochetina spp. on different growth stages of water hyacinth. J Plant Protection Res 49: 7-14.

17. Charudattan R, Labrada R, Center TD, Kelly-Begazo C (1995) Strategies for Water Hyacinth Control. Aquatic Plant Control Res Laboratory Fort Lauderdale, Florida, USA.

18. Smith-Fiola D, Gill S (2014) Vinegar: An alternative to glyphosate. University of Maryland Extension, Central Maryland Research and Education Center, USA.

19. Stubbs TL, Kennedy AC (2012) Microbial weed control and microbial herbicides In: "Herbicides - Environmental Impact Studies and Management Approaches. pp: 135-166.

20. Bambang GS, Moenandir J (2000) Effect of herbicide glyphosate and legin to nodulasi peanut plant (Arachis hypogaea L.). Agrosains 2: 43-49.

21. El-Shahawy TAE (2015) Chemicals with a natural reference for controlling water hyacinth, Eichhornia crassipes (Mart.) Solms. J Plant Protection Res 55: 3.

22. Taye T, Rezene F, Firehun $Y$ (2007) Invasive alien weed species in Ethiopia: Biology, distribution and importance, and available control measures. Rev Weed Sci 10: 33-39. 